The Review of Finance and Banking

print ISSN 2067-2713, online ISSN 2067-3825

Volume 11, Issue 2, Year 2019

http://dx.doi.org/10.24818/rfb.19.11.02.02, Pages 59-78

\title{
THE IMPACT OF DIVIDEND EVENTS ON STOCK RETURNS: FINDINGS ON COMPANIES LISTED ON THE BUCHAREST STOCK EXCHANGE
}

\author{
HANAAN YASEEN AND RUXANDRA TRIFAN
}

\begin{abstract}
This study investigates market reactions to different dividend events by analyzing abnormal returns. Based on a database of 45 companies listed on Bucharest Stock Exchange, for the period of 2011-2016, we found that the Declaration Date, Ex-Dividend Date and Record Date could have significant influence on stock returns in Romania. Using an event window of 41 days around the dividend announcement, we find evidence that shareholders react as a response to new information regarding dividend policy. However, further research should be performed in order to see the exact market reaction when the company decides to increase, decrease or keep the same level of dividends. Using the event study methodology, we find evidence that dividend events influence significantly the returns after the event, and only for some cases, they affect the returns before the event.
\end{abstract}

\section{INTRODUCTION}

There is an abundance of evidence which associates the announcements of changes in dividends with abnormal share price performance.

Dividend policy is one of the most important corporate financial decisions and it comprises information that could influence the stock return through different channels, resulting in possible excess returns. Firstly, the dividend information could affect the stock returns through the cash-flow channel with ultimate effect on the company's profitability in the future. This is also in line with signaling theory of dividends which states that dividends could be also used to signal better performance of the company in the future (Bhattacharya, 1979; Kalay, 1982; Esqueda, 2016). On the other hand, dividends could give information regarding company future investments. For example, if a company decides to distribute higher dividends, it means that investments could be done at a higher cost using external resources, or it means that company does not have investment opportunities. Therefore, the stock price could decline after the dividend announcement. A third effect on stock price could be through the role of dividends to mitigate the agency conflicts. If the dividends serve as a tool to minimize the agency problems between shareholders and managers (Easterbrook, 1984; Lin et al., 2017) the prices could adjust based on the information that a company decides to distribute higher or lower dividends. These channels and the dividend information effect on the stock price is applicable in both emerging or developed countries. However, the anomalies-based-trading (technical anomalies, calendar anomalies, mood anomalies, etc) effects are more significant in emerging stock markets, characterized by lower liquidity, efficiency and transparency (Schwert, 2003; Chordia et al., 2014). Therefore, we expect that the abnormal returns identified in Romania,

Received by the editors April 10, 2019. Accepted by the editors July 24, 2019.

Keywords: Key words: Cash Dividends, Dividend Events, Event Study, Market Reaction, Stock Returns. JEL Classification: G35, G14.

Hanaan Yaseen*, corresponding author, PhD Student, Department of Finance and CEFIMO, Bucharest University of Economic Studies, Bucharest, Romania. E-mail: hanaan.yaseen@fin.ase.ro.

Ruxandra Trifan, PhD Student, Department of Finance, Bucharest University of Economic Studies, Bucharest, Romania. E-mail: ruxandra.trifan@fin.ase.ro.

This paper is in final form and no version of it will be submitted for publication elsewhere. 
as being an emerging market, are more significant than in other developed countries, where the stock market is characterized by a higher level of efficiency and transparency.

The evidences indicate that the market reacts as a response to the new information received. The dividend increase announcement is associated with significant positive abnormal/excess returns and the decrease announcement are associated with significant negative abnormal/excess returns, while the announcement of no-changes in dividends produce only normal returns for shareholders (De Cesari and Huang-Meier, 2015). This market phenomenon is known as the dividend announcement effect.

The main goal of this paper is to determine to which extent the Romanian market share prices react based on dividend announcements and the possibility of attaining abnormal returns if trading around these events.

Romania represents an interesting investment environment. Being a former communist country within the Central and Eastern European Region, it is still a frontier market. Therefore, we expect these events to have a greater impact on local investors. Secondly, it provides a supportive fiscal environment for institutional investors. In 2015, the dividend tax and the capital gains tax were lowered to $5 \%$ and $10 \%$ respectively, below the once flat income tax rate of $16 \%$. In the third place, it offers a competitive trading framework, but also a facile investors' access into the market. Therefore, we consider that our article contributes to the understanding of the Romanian capital market behavior and the anomalies that may shortly cause fluctuations in stocks performances.

The main results of the study show that there might be significant abnormal returns (AR) around the dividend events. The Dividend Declaration Date (announcement date) has an impact over the abnormal returns usually after the event date. Also, the cumulative average abnormal return (CAAR) reached on an event window of 41 days, is positive and significant from statistical point of view for some years (2011 and 2014) and negative and significant for other years (2015). Negative cumulative average abnormal returns are registered before and after the ex-dividend date. Except for 2012, in all analyzed years the CAAR is significant from statistical perspective. We found also evidence that the Record Date of Dividends could lead to a negative abnormal returns. Both AR and CAAR are significant for the same event window, for specific dates around the dividend record moment.

The study can be helpful for active practitioners who are looking to increase their wealth from potential abnormal returns from shares listed on Bucharest Stock Exchange. It has been proved in the past literature concerning the Romanian capital market that prices reflect very quickly the information received from different dividend events (Dragotă et al., 2004). On the other hand, some other studies found a slower reaction of share prices in Romania, when analyzing the capital increases (Todea and Metes, 2005). Based on our knowledge, an updated event study analyzing the dividend events impact on the market reaction in Romania, was not performed in the last 10 years.

Therefore, we find it useful for investors, but also for researchers who would like to see how quickly and when are the most significant abnormal returns when it comes to the important dates regarding the dividend policy. Also, the case of Romania could represent a good example for other emerging markets, hence the results of the study could be used to anticipate the stock reaction around the dividend dates in other countries.

The remainder of this article is structured as follows: section 2 displays the theoretical framework on this matter, section 3 describes the data and methodology, section 4 reports the main empirical findings, and section 5 concludes.

\section{Related literature}

The past literature on the issue of long-term performance of dividend-changing companies have been conducted (mostly using US data). They analyze the extreme dividend changes such as dividend initiations and omissions (Healy and Palepu, 1988) or dividend reductions (Woolridge and Ghosh, 1985; Jensen and Johnson, 1995). However, for this study, we only 
check if there are any significant abnormal returns registered around the dividend events and then, in a further study we would investigate the impact of the specific dividend changes.

Therefore, our main scope is to analyze the events in relation to the dividend payments and their effect on the stock prices and check for the existence of abnormal returns and cumulative abnormal returns obtained under these circumstances.

2.1. Dividend dates and potential impact on the value of shares. As there are a lot of rules and procedures in corporate finance concerning dividend payments announcements and changes in the dividend policy, we present a brief description of the important dates regarding the communication of such dividends:

1. Declaration Date - is the announcement that the company's board of directors approved the payment of the dividend.

2. Reference Date - is the date set by the board of directors (in the case of the single management system) or the directorship (in the case of the dual-management system) of the joint-stock company that are taken into account for determining the shareholder's status. If, for example, a person holds shares within the company, then he is the shareholder entitled to participate and vote at the general meeting.

3. General Assembly Meeting - within this meeting, the shareholders decide the dividend policy.

4. Ex-Dividend Date - is the date on which investors are cut off from receiving a dividend. If for example, an investor purchases a stock on the ex-dividend date, that investor will not receive the dividend. This date is two business days before the holder-of-record date. The ex-dividend date is important as, from this date and forward, new stockholders will not receive the dividend. As a result, the stock price of the company will be reflective of this. For example, on and after the ex-dividend date, a stock most likely trade at lower price, as the stock price is adjusted for the dividend that the new holder will not receive.

5. Record date - is the date on which the stockholders who are to receive the dividend are recognized.

6. Payment date - the date on which the actual dividend is paid out to the stockholders of record.

For this study, we have chosen to analyze the possibility to register abnormal returns around the Declaration Date, Ex-Dividend Date and Record Date. We consider that these three events could have the most significant reactions coming from the shareholders and we provide reasoning and findings in the following sections.

2.2. Market reactions around dividend announcements. Researchers have examined the impact of dividend announcements on share prices from a variety of different perspectives and in a selection of different circumstances. Three main directions of these studies can be defined: stock price reaction to the announcement of changes in regular dividends, trading volume behavior around dividend announcements and market response to the announcement of major changes in a firm's dividend policy such as dividend initiations and/or omissions.

Firstly, a number of researchers have investigated the market reaction to the announcement of changes in regular dividends paid (Charest, 1978; Aharony and Swary, 1980; Benesh and Keown, 1984; Eades et al., 1985; Nissim and Ziv, 2001; Yllmaz and Gunay, 2006; Howatt et al., 2009). They showed that positive dividend changes are correlated with positive significant abnormal returns, whereas negative dividend changes were linked to negative abnormal returns. The common explanation relates to the signaling hypothesis and information content. Investors perceive certain information as good or bad based on the signals transmitted by the company's management in regards to its future performance (Miller and Rock, 1985; Ofer and Thakor, 1987). Dividend increases could be seen as signals of increased firm's earnings in the future and would lead to a stock price increase. Adversely, dividend decreases could signal poor firm's future prospects and would lead to stock prices' fall. Another explanation is provided through the free cash-flow hypotheses. It states that if company's management does not chose to pay 
dividends in case of cash flow left over after all investments made, then this cash flow would be inefficiently used or invested at a lower rate (below the cost of capital). Then, this would be translated into projects with negative net present value (e.g. Lang and Litzenberger, 1989). Moreover, there are also the behavioral implications of dividend payment. Frankfurter and Lane (1992) state that most of the investors prefer persisting and increasing dividend payouts instead of capital gains, and managers use these dividends to satisfy these investors. On the other hand, if investors prefer capital gains instead of dividend payouts, then there is a negative link between increasing/decreasing dividends and rising/falling stock prices. This is known as the clientele effect as suggested by Miller and Modigliani (1961).

Secondly, other researchers have analyzed the market response to the announcement of major changes in a firm's dividend policy such as dividend initiations and/or omissions (Pettit, 1972; Asquith and Mullins, 1983; Benesh et al., 1984; John and Lang, 1991). Also, a related research area concentrates on the announcement of special dividends as opposed to regular dividends (Brickley, 1983). However, we focus more on the events related to cash dividends and not on other special dividends (i.e. share repurchases).

Thirdly, there are studies considering the effects of a dividend announcement on trading volume patterns, share price volatility, the revision of analysts' forecasts (Ofer and Seigel, 1987; Gurgul, Mestel, and Schleicher, 2003; Yılmaz and Gunay, 2006) and the speed of any associated price adjustment (Patell and Wolfson, 1984). Arguments proposed to justify the market response to dividend announcements rest upon information asymmetry, in which case managers have access to detailed internal reports with data relating to the profitability of the firm. Hence, alterations in dividend policy convey managerial assessments of future profitability/cash flows of the firms to the outside investors (Bhattacharya, 1979; John and Williams, 1985; Miller and Rock, 1985). This argument was recognized by Miller and Modigliani (1961) even though they state that no relationship exists between the dividend policy and the market value of the firm. They admitted that "where a firm has adopted a policy of dividend stabilization with a longestablished and generally appreciated target payout ratio, investors are likely to (and hence have good reason to) interpret a change in the dividend rate as a change in the management's view of the future profit prospects of the firm" (Miller and Modigliani, 1961). In this context, dividend increases (decreases) could convey favorable (unfavorable) information about current and future profitability of firms to the outside investment community.

When talking about dividend events, most of the literature focuses on three main events, namely the announcement regarding company's decision to pay dividends, the ex-dividend date and the payment date. For example, Adelegan (2003) investigated Nigerian capital market efficiency by analyzing the stock prices' behavior to dividend announcements. Employing classical event study methodology, he concluded on the inefficiency of the local market. Gurgul et al. (2003) studied dividend changes in relationship to stock prices and trading volume with empirical evidence on the Austrian capital market. Their findings were in line with the dividend information content theory, but also with the efficient market hypothesis, information being rapidly incorporated in stock prices. Moreover, they obtain similar conclusions when looking at the trading volume. Three years later, Yilmaz and Gunai (2006) tested for any impact of cash dividend payments on Turkish stock prices and trading volume. Their results support the dividend signaling theory. Stock prices rose a few sessions before the dividend payment date and felt by less than the dividend amount on the ex-dividend date, continuing their downward trend after payment date. In the same time, stock prices could overreact or underreact based on information and news in the market. Veronesi (1999) found that stock markets overreact to bad news in good times and underreact to good news in bad times. Moreover, when trying to protect your investment against some "noise traders" it is likely to produce even higher volatility and greater time-varying expected returns. Also, if trying to protect against any changes in own uncertainty, this action will lead share prices to overreact to bad news in good times, respectively to underreact to good news in bad times. This can be explained by the loss aversion bias, the pain of losing being psychologically twice as powerful as the gaining sentiment, 
therefore higher risks would be taken to prevent or lower a loss than to realize a gain. However, with this study we are interested to find if dividend dates are still significant and if abnormal returns are registered around these dates. In a later stage, it could be interesting to analyze Romanian stock returns from behavioral perspective, considering the findings of this study.

With regards to the Romanian capital market and the dividend policy, there were a few papers that focused on the dividend policy's implications on firm value (e.g. Dragotă, 2003; Dragotă et al., 2009; Ivănescu and Ivănescu, 2009). However, as per our knowledge, this is the first study (at least in the last 10 years) conducted on Romanian market, that tries to find if there is an possibility to register abnormal returns around the dividend dates.

\section{Data and Methodology}

This paper investigates whether the dividend events could create premises to gain abnormal returns from holding shares listed on Bucharest Stock Exchange.

In terms of data gathering, we proceeded as follows. The dividend events days were acquired from the Corporate Department within the Bucharest Stock Exchange (BSE). Therefore, our data sample consists in 45 companies out of 86 firms listed on the local stock exchange. We considered only companies that distributed dividends across the years between 2011-2016. Stock prices for all companies, subject in our dataset, for the analyzed time horizon of 2011-2016 were collected from the Thomson Reuters Database. The descriptive statistics of the returns, calculated as per equation (1) below, are presented in Annex 1. In terms of local market return, we considered as benchmark a representative index, namely BET-XT. We have chosen this index because it encompasses the 25 most liquid shares traded on BSE and it covers the time period studied in this article. Data for market prices is available on the Stock Exchange website. To avoid the potential break in data we assumed the last price of the share as per its last transaction to be constant for the non-trading days.

We employed a standard event study approach to test for the existence of abnormal returns during dividend announcements' periods as described by Brown and Warner (1985) and MacKinlay (1997). Our assumption was that abnormal returns would be registered if the dividend information released to the market was seen as useful and surprising content. Also, the magnitude of these abnormal returns at the time of the announcement would indicate if the event's impact was significant or not on shareholders' wealth.

Out of the total 6 dividend dates presented in the above section, we chose to analyze the effect of 3 of them, namely the declaration date, the ex-dividend date and the record date. We considered these ones to lead to the most significant market reactions for several reasons. In the first place, the declaration date/the company's dividend announcement date sends a signal to market players regarding the management expectations of a change in the firm's future performance. Therefore, market would react by revaluing company's shares. Second, the exdividend date and the record date are the essential dates, as they determine who is eligible or not to receive the dividend. In order to receive the dividend, one has to own a stock before the ex-dividend date. These two dates can provide evidence for market timing strategies. Investors might acquire shares just prior to the ex-dividend date, wait for the dividend payment and sell them shortly afterwards.

One might say that the dividend payment date could be also significant. We excluded this one from our analysis as we assumed that all information would be encompassed in stock prices until the payment moment and the prices would have already been adjusted with the dividend amount.

The event study timeline is presented in Figure 1: 


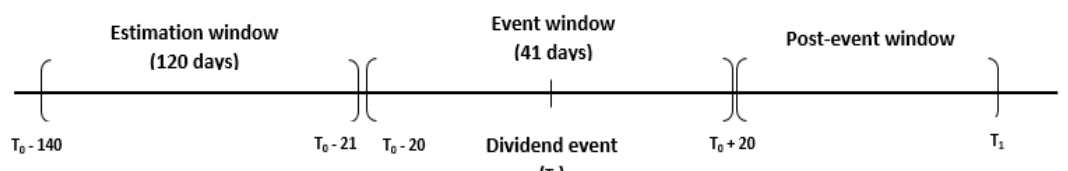

$\left(T_{0}\right)$

Figure 1: Timeline of the event study

The first step in the study is to calculate daily returns of the shares and of the market index. The original data represents the closing price of shares and closing value of the market index. Equation (1) is used to find the daily return of the share $i$ in the day $t$.

$$
R i t=\ln \left(\frac{P_{i t}}{P_{i t-1}}\right)
$$

Where $R_{i t}$ is the daily return of the asset or of the market on day $t, P_{i t-1}$ is the closing price of the asset or of the market on day $t-1$, and $P_{i t}$ is the closing price of the market and of the asset on day $t$.

Figure 2 shows the evolution of the share price for ALR in 2011 and the chronology of all the dividend events. Graphs for other companies listed on BSE, for all years and dividend important dates are available upon request.

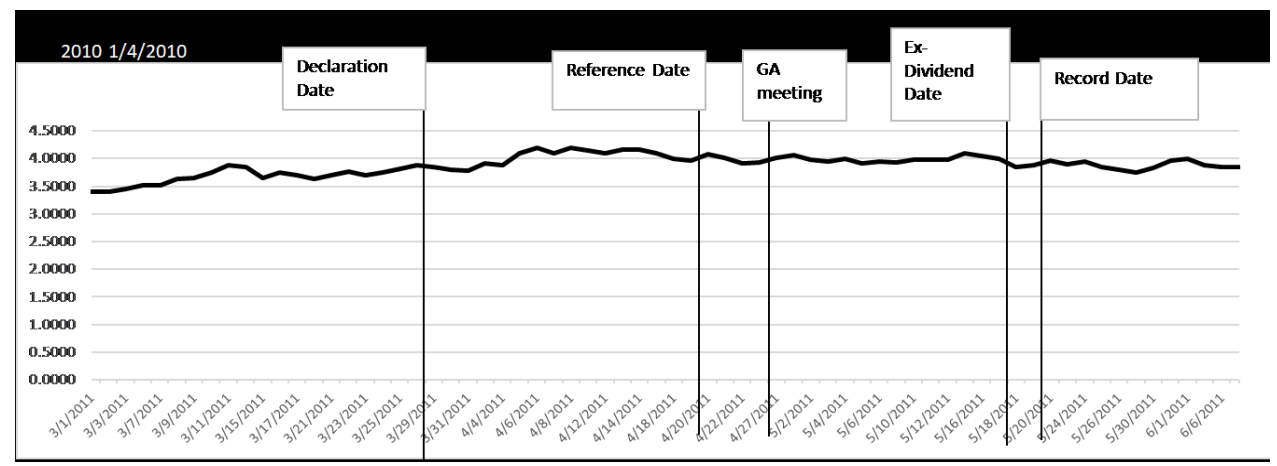

Figure 2: Evolution of the Share Price for ALR in 2011 and the chronology of all the dividend events

We noted "Day 0" as being the dividend event, namely the dividend announcement date, ex-dividend date and the record date. Following Campbell et al. (1997) we chose a 120-day estimation window prior to the event. With respect to the event window, we considered the maximum length including 41 trading days that surrounds symmetrically the announcement day. Therefore, the study examines abnormal return behavior over a window of 41 days before and after the event, (ex. Day -20, Day -19, and same for all days before reaching Day 0, where Day 0 is the announcement day).

The return behavior of 45 companies' shares, listed on the Bucharest Stock Exchange, around dividend events, is examined using abnormal and cumulative abnormal returns calculated over different periods.

Assuming normally distributed security returns, we use the market model to estimate the expected return of the asset:

$$
R_{i t}=\alpha_{i}+\beta_{i} R_{M t}+\varepsilon_{i t}
$$

where, $R_{i t}$ is the daily return of each security for the last 120 days prior to the event window, $R_{M t}$ is the daily return of the market, measured through BET XT for the last 120 days before the event window, $\alpha_{i}$ is the excess return above the usual performance of the market (Constant 
of the model), $\beta_{i}$ is the volatility of the asset relative to the market return and lastly, $\varepsilon_{i t}$ is the error term of the model.

The abnormal returns are generated by the market model as follows:

$$
A R_{i t}=R_{i t}-\left(\alpha_{i}+\beta_{i} R_{M t}\right)
$$

where, $A R_{i t}$ is the daily abnormal return of share $i$ on day $t, R_{i t}$ is the realised return of share $i$ on day $t$ and $R_{M t}$ is the return of BET XT share price index on day $t$. The $\alpha$ and $\beta$ parameters are estimated using OLS regressions for previous 140 days before the event (120 before the event window of 20 days).

After calculating the ARs for each event, we also determined the average abnormal returns (AAR) for the entire sample, for each day of the window (-20 days before and +20 days after the event). A simple average was conducted. Then, cumulative abnormal returns are defined as follows:

$$
C A R_{i t}=\sum A R_{i t}
$$

At the end, for each event, we calculated the cumulative average of abnormal return (CAAR), on all companies, for the interval $(-20,+20)$ days around the event date.

3.1. Testing the significance of an event on the behavior of shares. Under the null hypothesis that the dividend event does not have any impact on the mean returns, there is null probability of registering abnormal returns.

A common issue in event studies is the event-date clustering, that leads to cross-sectional correlation of the abnormal returns and event-induced volatility changes. This could be also the case here, as we focus on some specific dividend dates which happen for several companies in the same day(s). Moreover, the distortions from the event-induced volatility is an important issue when events are clustered. Thus, there is a need for different significance tests, both parametric (T-test, (adjusted) Patell test, (adjusted) cross-sectional test, (adjusted) standardized crosssectional test, etc.) and non-parametric tests (i.e. Generalized Rank Tests and Sign Test,), to overcome the over/under-rejections of the null hypothesis.

Traditional t-statistic tests (or variations of them) are used to test the significance of the cumulative abnormal return for each event:

$$
t_{C A R}=\overline{C A R}_{i t} /\left(\sigma\left(C A R_{i t}\right) / \sqrt{n}\right)
$$

However, the t-statistic may impose several issues regarding standard deviation that might lead to rejection of the null hypothesis. We also use the Patell's test, which standardizes the abnormal returns within the event window. The averages (CAAR and AAR) are tested using Patell Z test. Please refer to Patell (1976) for more details regarding the Patell Z test. It is a widely used test statistic in event studies. In the first step, Patell $(1976,1979)$ suggested to standardize each ARi before calculating the test statistic by the forecast-error corrected standard deviation.

As a robustness check, we also performed the Precision Weighted CAAR (PWCAAR) for a more relevant CAAR. Please refer to Boehmer et al. (1992) and Rani (2016) for more details regarding formula of PWCAAR.

Both the t-test and the Patell test (Patell, 1976) are prone to event-date clustering (Cowan \& Sergeant, 1996; Kolari \& Pynnonen, 2010). Furthermore, when dealing with non-normal returns, low prices or little liquidity, as in the case of frontier/emerging markets, the Patell test may reject the null hypothesis. Hence, to overcome the fact that daily returns' distributions are more fat-tailed than normal distributions, but also to secure against event clustering, we performed some other robustness checks. We used as non-parametric tests the Corrado Rank Test as proposed by Corrado and Zivney (1992), but also the Generalized Rank Test as in Kolari and Pynnönen (2011). The advantages of these two are that they can identify small 
levels of abnormal returns, but also account for cross-correlation of returns and event-induced volatility.

\section{Empirical Results}

4.1. Market Reaction around the Dividend Declaration Date. The results show that there might be a significant market reaction around the dividend announcement date. We used an estimation window of 120 days and an event window of 41 days. The main results are presented in Table $1^{1}$. The main conclusion, that the companies could register significant Abnormal Returns in the period around the Declaration Date, is presented below:

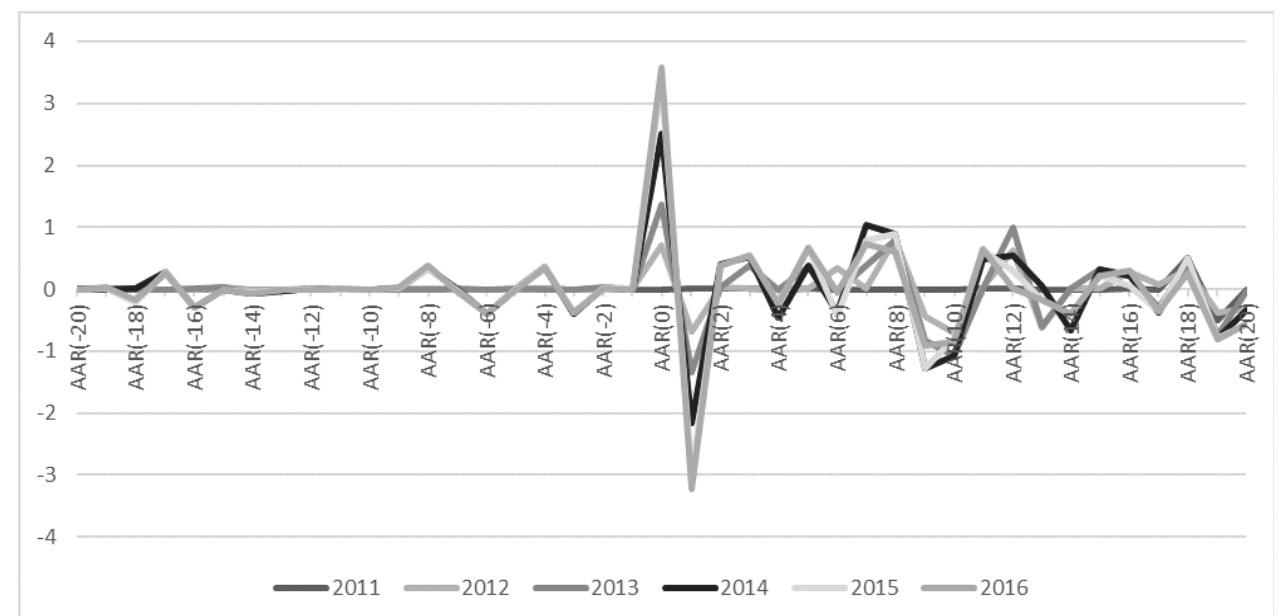

Figure 3: AAR for all Companies per Day $(-20,+20$ days $)$ around Declaration Date

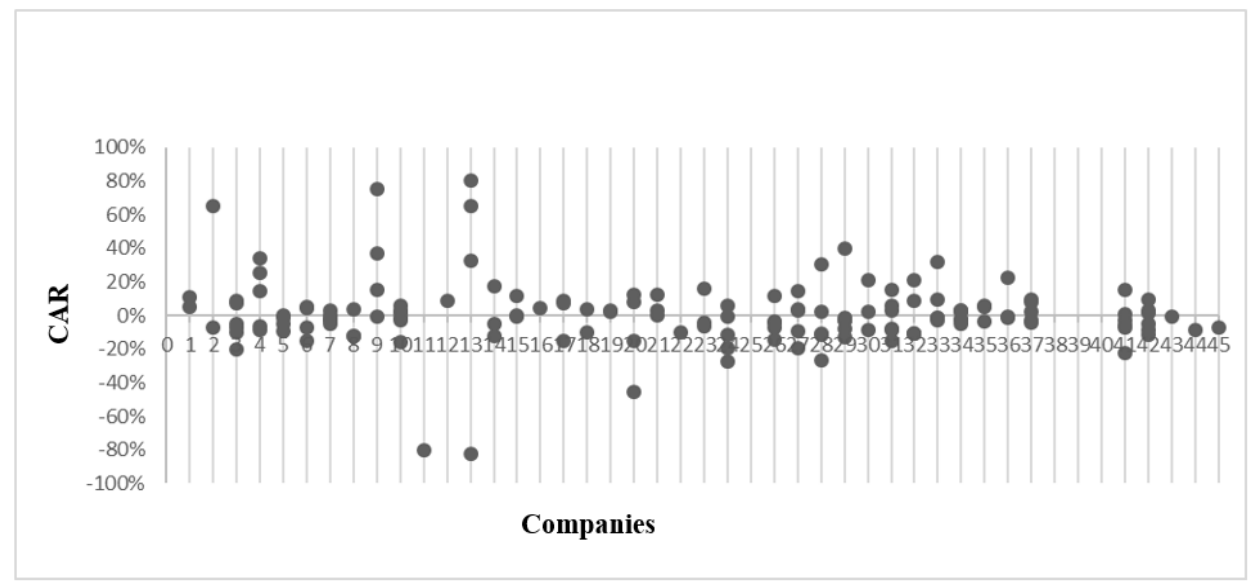

Figure 4: Cumulative Abnormal Return per Company for $(-20,+20)$ days window around the Declaration Date

It can be seen that there are high abnormal returns around the Declaration Date and high cumulative abnormal returns within the 41 days window. Also, after the declaration date, starting with Day 0, the average abnormal returns are more volatile than before the declaration date. Most of the AAR on the day of declaration and the day after the declaration are statistically significant at $10 \%$ level. Then, days 8, 9 and 10 are usually (statistically) significant. Table 1 presents the summary of the data calculated based on the presented methodology:

\footnotetext{
${ }^{1}$ All other detailed data regarding daily AR for each year are available upon request.
} 


\begin{tabular}{|c|c|c|c|c|c|}
\hline & $\mathrm{AR}$ & A A R & CAR $(-20,+20)$ & $\mathrm{CAAR}(-20,+20)$ & $\begin{array}{l}\text { Precision } \\
\text { Weighted CAAR }\end{array}$ \\
\hline $\begin{array}{c}2011 \\
(19 \text { companies })\end{array}$ & $\begin{array}{l}\text {-Day }(+1) \text { is the } \\
\text { most significant } \\
\text { day (based on } \\
\text { t-statistic test) } \\
\text { - Significant } \\
\text { AR registered } \\
\text { for } 32 \% \text { of the } \\
\text { companies (based } \\
\text { on t statistic test) }\end{array}$ & $\begin{array}{l}\text {-Day }(+1) \text { Day } \\
(+2) \text { Day }(+3) \\
\text { are the most sig- } \\
\text { nificant from sta- } \\
\text { tistical point of } \\
\text { view (based on } \\
\text { Patell Z signifi- } \\
\text { cance test }\end{array}$ & $\begin{array}{l}\text { Significant CAR } \\
\text { registered for } 32 \% \\
\text { of the companies } \\
\text { (based on } t \\
\text { statistic test }\end{array}$ & $\begin{array}{l}\text {-It is } 5.2 \% \text { and } \\
\text { significant from } \\
\text { statistical point } \\
\text { of view (based } \\
\text { on Patell Z } \\
\text { significance test) }\end{array}$ & $\begin{array}{l}\text {-It is } 5.2 \% \text { and } \\
\text { significant from } \\
\text { statistical point } \\
\text { of view (based } \\
\text { on Patell Z } \\
\text { significance test) }\end{array}$ \\
\hline $\begin{array}{c}2012 \\
(26 \text { companies })\end{array}$ & $\begin{array}{l}\text {-Day }(0) \text { and Day } \\
(+1) \text { are the most } \\
\text { significant days } \\
\text { - Significant AR } \\
\text { registered for } 23 \% \\
\text { of the companies }\end{array}$ & $\begin{array}{l}\text {-Day }(+0) \text { Day } \\
(+1) \text { Day } \quad(+6) \\
\text { Day }(+8) \text { are the } \\
\text { most significant } \\
\text { from statistical } \\
\text { point of view }\end{array}$ & $\begin{array}{l}\text {-Significant CAR } \\
\text { only for } 1 \text { com- } \\
\text { pany (SIF 2) }\end{array}$ & $\begin{array}{l}\text {-It is } 5.4 \% \text { and } \\
\text { not significant } \\
\text { from statistical } \\
\text { point of view } \\
\text { (based on Patell } \\
\text { Z significance } \\
\text { test) }\end{array}$ & $\begin{array}{l}\text {-It is } 4.35 \% \text { and } \\
\text { not significant } \\
\text { from statistical } \\
\text { point of view } \\
\text { (based on Patell } \\
\mathrm{Z} \text { significance } \\
\text { test) }\end{array}$ \\
\hline $\begin{array}{c}2013 \\
(25 \text { companies })\end{array}$ & $\begin{array}{l}\text {-Day }(-5), \quad \text { Day } \\
(0), \text { Day }(1), \text { Day } \\
(15), \text { Day (17), } \\
\text { Day (18) the most } \\
\text { significant - Sig- } \\
\text { nificant for } 10 \% \text { of } \\
\text { the companies }\end{array}$ & $\begin{array}{l}\text {-Day (-5) Day (0) } \\
\text { Day (1) Day (3) } \\
\text { Day (10) Day (15) } \\
\text { Day (16) Day (20) } \\
\text { are the most sig- } \\
\text { nificant from sta- } \\
\text { tistical point of } \\
\text { view }\end{array}$ & $\begin{array}{l}\text {-Significant CAR } \\
\text { only for } 2 \text { compa- } \\
\text { nies (FP, SIF } 3 \text { ) }\end{array}$ & $\begin{array}{l}\text {-It is } 19.46 \% \text { and } \\
\text { not significant } \\
\text { from statistical } \\
\text { point of view } \\
\text { (based on Patell } \\
Z \quad \text { significance } \\
\text { test) }\end{array}$ & $\begin{array}{l}\text {-It is }-1 \% \text { and } \\
\text { not significant } \\
\text { from statistical } \\
\text { point of view } \\
\text { (based on Patell } \\
\text { Z significance } \\
\text { test) }\end{array}$ \\
\hline $\begin{array}{c}2014 \\
(25 \text { companies }\end{array}$ & $\begin{array}{l}\text {-Day }(0), \text { Day } \\
(+1) \text { and Day } \\
(+5) \text { are the } \\
\text { most significant } \\
\text { days - Significant } \\
\text { for } 16 \% \text { of the } \\
\text { companies }\end{array}$ & $\begin{array}{l}\text {-Days between - } \\
6 \text { and }+20 \text { are } \\
\text { the most signifi- } \\
\text { cant from statisti- } \\
\text { cal point of view }\end{array}$ & $\begin{array}{l}\text {-Significant CAR } \\
\text { only for } 5 \text { compa- } \\
\text { nies (SIF 2, TEL, } \\
\text { TGN, SIF 2, FP) }\end{array}$ & $\begin{array}{l}\text {-It is } 5.75 \% \text { and } \\
\text { significant from } \\
\text { statistical point } \\
\text { of view (based } \\
\text { on Patell Z } \\
\text { significance test) }\end{array}$ & $\begin{array}{l}\text {-It is } 6.4 \% \text { and } \\
\text { significant from } \\
\text { statistical point } \\
\text { of view (based } \\
\text { on Patell Z } \\
\text { significance test) }\end{array}$ \\
\hline $\begin{array}{c}2015 \\
(33 \text { companies })\end{array}$ & $\begin{array}{l}\text {-Day }(+1), \text { Day } \\
(+2), \text { Day }(+4) \\
\text { and Day }(+5) \text { are } \\
\text { the most signifi- } \\
\text { cant days - Signif- } \\
\text { icant for } 14 \% \text { of } \\
\text { the companies }\end{array}$ & $\begin{array}{l}\text {-Day }(-18) \text {, Day (- } \\
13) \text {, and Days be- } \\
\text { tween } 0 \text { and } 13 \\
\text { are the most sig- } \\
\text { nificant from sta- } \\
\text { tistical point of } \\
\text { view }\end{array}$ & $\begin{array}{l}\text {-Significant CAR } \\
\text { only for } 3 \text { compa- } \\
\text { nies (BVB, TEL, } \\
\text { TGN) }\end{array}$ & $\begin{array}{l}\text {-It is }-21 \% \text { and } \\
\text { significant from } \\
\text { statistical point } \\
\text { of view (based } \\
\text { on Patell Z } \\
\text { significance test) }\end{array}$ & $\begin{array}{l}\text {-It is }-2.1 \% \text { and } \\
\text { significant from } \\
\text { statistical point } \\
\text { of view (based } \\
\text { on Patell Z } \\
\text { significance test) }\end{array}$ \\
\hline $\begin{array}{c}2016 \\
(32 \text { companies })\end{array}$ & $\begin{array}{l}\text {-Day }(+1), \text { Day } \\
(+2), \text { Day }(+5) \\
\text { Day }(+7) \text { are the } \\
\text { most significant } \\
\text { days - Significant } \\
\text { for } 11 \% \text { of the } \\
\text { companies }\end{array}$ & $\begin{array}{l}\text {-Day }(-3), \text { Day } \\
(5), \text { Day }(7), \text { Day } \\
(9), \text { Day (10) are } \\
\text { the most signifi- } \\
\text { cant from statisti- } \\
\text { cal point of view }\end{array}$ & $\begin{array}{l}\text {-Significant CAR } \\
\text { only for } 1 \text { com- } \\
\text { pany (FP) }\end{array}$ & $\begin{array}{l}\text {-It is } 6.57 \% \text { and } \\
\text { not significant } \\
\text { from statistical } \\
\text { point of view } \\
\text { (based on Patell } \\
\mathrm{Z} \text { significance } \\
\text { test) }\end{array}$ & $\begin{array}{l}\text {-It is }-2.7 \% \text { and } \\
\text { not significant } \\
\text { from statistical } \\
\text { point of view } \\
\text { (based on Patell } \\
\mathrm{Z} \text { significance } \\
\text { test) }\end{array}$ \\
\hline
\end{tabular}


Also, the CAAR results show us statistically significant values for all years, between $-21 \%$ and $+6.6 \%$. However, the sign is different from one year to another due to the different decisions taken by the company in relation to the dividend policy. It could be a negative average when more companies decide to decrease the level of dividend and it could be a positive average when the company decides to increase the dividends. Therefore, further research should be performed to find the association between dividend announcement and the share price when companies decide to increase, decrease or keep the same level of dividends.

In terms of non-parametric tests, the results show that we can reject the null hypothesis (CAAR is 0) with a rejection rate between 67\% (based on Corrado Rank test) to100\% (based on Generalized Rank Z Test, Generalized Rank T Test, Cowan Generalized Sign Z Test). The rejection rate is calculated as total number of cases when we reject the null hypothesis (i.e. in some years we can reject in some years we cannot reject it) out of total number of years. The results of non-parametric tests are presented in Annex 2.

4.2. Ex-Dividend Date influence on stock returns. We found that there is a significant market reaction around the ex-dividend date. The most significant days are between $(-1,+7)$ - at $1 \%$ level of confidence. Also, at $5 \%$ level of confidence, the AAR between day -12 and day -2 are also significant, based on Patell Z-test. The Average Abnormal Return for all companies listed on BSE is presented below:

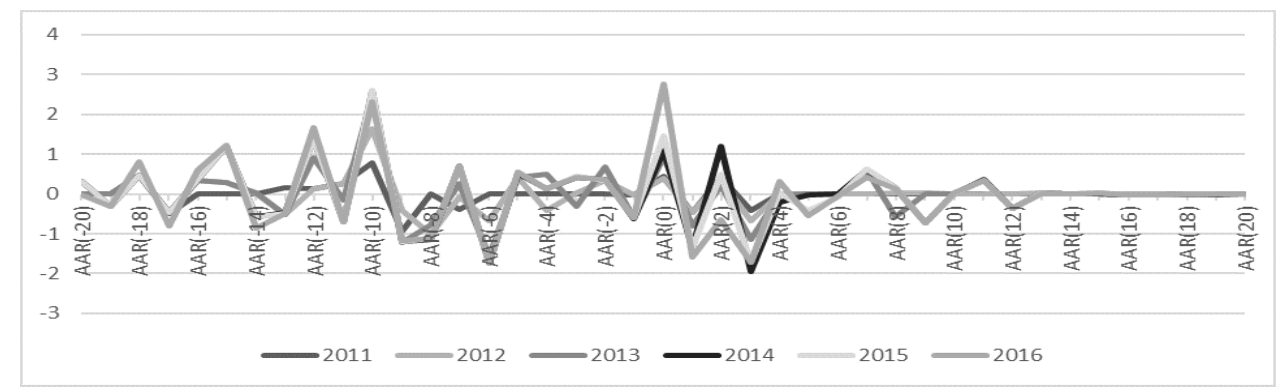

Figure 5: AAR for all Companies per Day (-20, +20 days) around Ex-Dividend Date

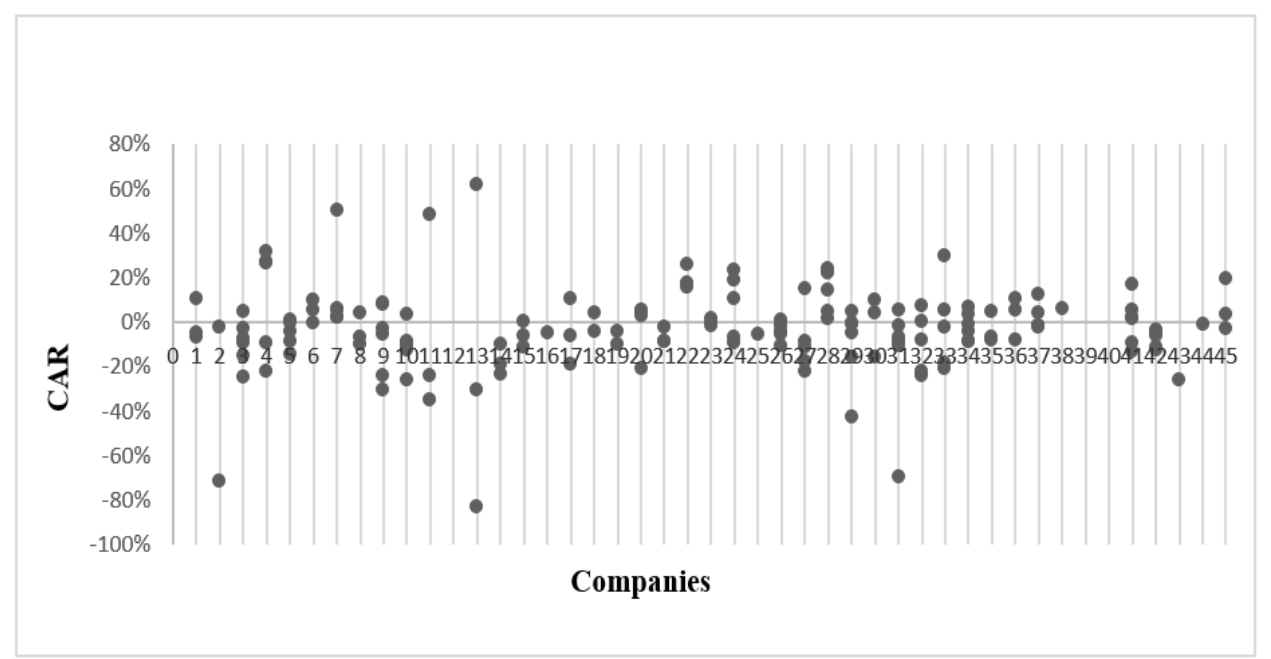

Figure 6: Cumulative Abnormal Return per Company for $(-20,+20)$ days window around the Ex-Dividend Date

There are around $20-25 \%$ of CARs which are significant from statistical point of view (based on t statistic test). 
The CAARs for all companies for the period of 2011-2016 are negative and between $(-43 \%$, $-1 \%$ ). They are all significant different from 0 based on Patell Z-test. In Table 2 we present the detailed result when analyzing the Market Reaction over the Ex-Dividend Date.

\begin{tabular}{|c|c|c|c|c|c|}
\hline & $\mathrm{AR}$ & $\mathrm{AAR}$ & CAR $(-20,+20)$ & CAAR $(-20,+20)$ & $\begin{array}{l}\text { Precision } \\
\text { Weighted CAAR }\end{array}$ \\
\hline & ( $\mathrm{T}$ test) & (Pattel Z test) & $(\mathrm{T}$ test $)$ & (Pattel Z test) & (Pattel Z test) \\
\hline $\begin{array}{c}2011 \\
(20 \text { companies })\end{array}$ & $\begin{array}{l}\text { The most signif- } \\
\text { icant days: Day } \\
\text { (0) and Day (1). } \\
\text { Significant AR } \\
\text { for: } 12 \% \text { of the } \\
\text { companies-days } \\
\text { obs.. D (0) Signif- } \\
\text { icant for the } 55 \% \\
\text { of the companies. }\end{array}$ & $\begin{array}{l}\text { The most signifi- } \\
\text { cant days: days } \\
\text { between Day (-13) } \\
\text { to Day (-7) and } \\
\text { from Day (-1) to } \\
\text { Day (3) }\end{array}$ & $\begin{array}{l}\text { Significant CAR } \\
\text { for: } 25 \% \text { of the } \\
\text { companies }\end{array}$ & $-6.67 \% *$ & $-4.56 \% *$ \\
\hline $\begin{array}{c}2012 \\
(26 \text { companies })\end{array}$ & $\begin{array}{l}\text { The most signif- } \\
\text { icant days: Day } \\
(-1) \text { to Day (3) } \\
\text { - Significant AR } \\
\text { for: } 13 \% \text { of the } \\
\text { companies-days } \\
\text { obs.. D (0) Signif- } \\
\text { icant for the } 54 \% \\
\text { of the companies. }\end{array}$ & $\begin{array}{l}\text { The most signifi- } \\
\text { cant days: days } \\
\text { between Day (-15) } \\
\text { to Day (0) and } \\
\text { also Day (2) and } \\
\text { Day (3) }\end{array}$ & $\begin{array}{l}\text { Significant CAR } \\
\text { for: } 23 \% \text { of the } \\
\text { companies }\end{array}$ & $-1 \%$ & $-2.58 \%$ \\
\hline $\begin{array}{c}2013 \\
(25 \text { companies })\end{array}$ & $\begin{array}{l}\text { The most signif- } \\
\text { icant days: Day } \\
(-4) \text { to Day }(+2) \\
\text { Significant AR } \\
\text { for: } 16 \% \text { of the } \\
\text { companies-days } \\
\text { obs. D (0) Signifi- } \\
\text { cant for the } 56 \% \\
\text { of the companies. }\end{array}$ & 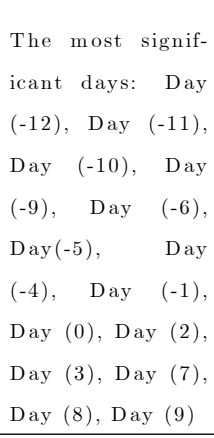 & $\begin{array}{l}\text { Significant CAR } \\
\text { for: } 4 \text { companies } \\
\text { (ARTE, SIF } 2, \\
\text { SIF 4, SIF 3) }\end{array}$ & $-33 \% *$ & $-4.38 \% *$ \\
\hline $\begin{array}{c}2014 \\
(25 \text { companies })\end{array}$ & $\begin{array}{l}\text { The most signifi- } \\
\text { cant days: Day (- } \\
\text { 11), Day (-2) to } \\
\text { Day (+2). Signif- } \\
\text { icant AR for: } 16 \% \\
\text { of the companies- } \\
\text { days obs.. D }(0) \\
\text { Significant for the } \\
56 \% \text { of the com- } \\
\text { panies. }\end{array}$ & $\begin{array}{l}\text { The most signifi- } \\
\text { cant days: Days } \\
\text { between }-20 \text { and } \\
+6\end{array}$ & $\begin{array}{l}\text { Significant CAR } \\
\text { for: } 4 \text { companies } \\
\text { (CNTE, TGN, } \\
\text { BRD, BVB) }\end{array}$ & $-1 \% *$ & $-3 \% *$ \\
\hline
\end{tabular}




\begin{tabular}{|c|c|c|c|c|c|}
\hline $\begin{array}{c}2015 \\
\text { (36 companies) }\end{array}$ & $\begin{array}{l}\text { The most signif- } \\
\text { icant days: Day } \\
\text { (0), Day (1), Day } \\
\text { (2) and Day ( } 3 \text { ). } \\
\text { Significant AR } \\
\text { for: } 8.3 \% \text { of the } \\
\text { companies-days } \\
\text { obs.. D (0) Signif- } \\
\text { icant for the } 47 \% \\
\text { of the companies. }\end{array}$ & $\begin{array}{l}\text { The most signif- } \\
\text { icant days: Day } \\
\text { (0) to Day (5), } \\
\text { and Days }\end{array}$ & $\begin{array}{l}\text { Significant CAR } \\
\text { for: } 8 \text { companies } \\
\text { (SIF } 2, \text { SIF } 5, \\
\text { SNG, OIL, EL, } \\
\text { COTE, CNTE, } \\
\text { BVB) }\end{array}$ & $-18 \% *$ & $-6.36 \% *$ \\
\hline $\begin{array}{c}2016 \\
(32 \text { companies })\end{array}$ & 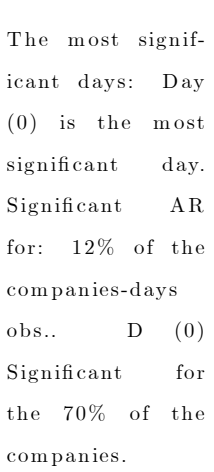 & $\begin{array}{l}\text { The most signifi- } \\
\text { cant days: Days (- } \\
6) \text {, Day (-5) and } \\
\text { Day (0) to Day } \\
(+7)\end{array}$ & $\begin{array}{l}\text { Significant CAR } \\
\text { for: } 4 \text { companies } \\
\text { (BVB, TEL, } \\
\text { TLV, SNN) }\end{array}$ & $-43 \% *$ & $-5.9 \% *$ \\
\hline \multicolumn{6}{|c|}{ Source: own calculation based on the methodology presented in section 3} \\
\hline \multicolumn{6}{|c|}{$\begin{array}{l}\text { Note: } * \text { - significant at } 90 \% \text { significance level. The indicators without "*" are not significant from statistical } \\
\text { point of view. }\end{array}$} \\
\hline
\end{tabular}

Here, the CAARs $(-20,+20)$ are statistically significant for all years except 2012 based on the Patell Z significance test. All CAARs obtained are negative and vary between $-43 \%$ and $-1 \%$. These results suggest that a significant holding period of 41 days around the ex-dividend date would translate in significant negative returns due to the behavior of dividend capture investors.

In the case of Ex-Dividend date, the rejection rate of non-parametric tests is between $50 \%$ to $83 \%$, which means that for CAAR is significant for most of the cases and we can accept that CAAR is significantly different from 0 .

4.3. Market Reaction around the Record date. Figure 7 shows the level of AAR per day for all 45 companies listed on Bucharest Stock Exchange. It can be seen that from Day (-12) to Day (-8) and between Day (-2) to Day (+2) some significant AAR were registered. They are also statistically significant. However, the magnitude of these AAR is lower in comparison to the ex-dividend date.

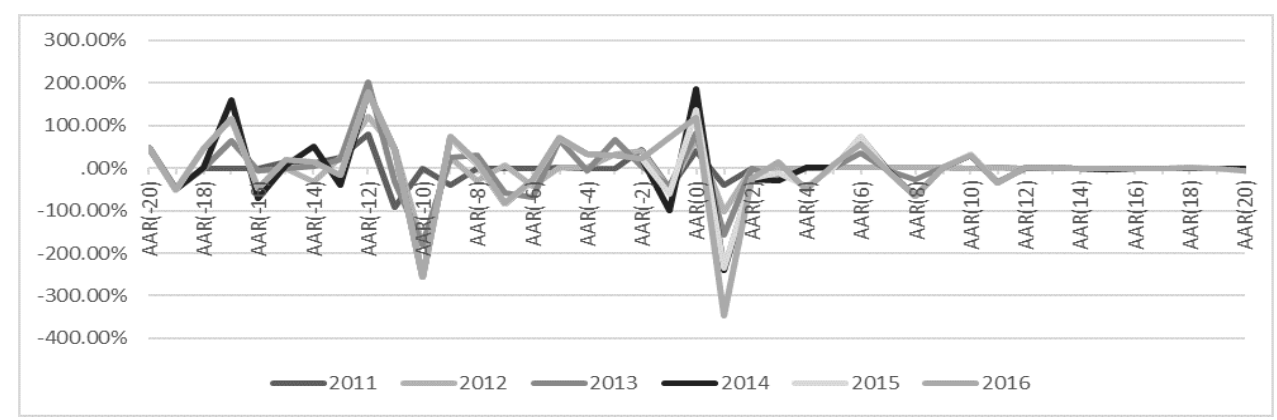

Figure 7: AAR for all Companies per Day $(-20,+20$ days $)$ around Record Date 
Table 3 reveals that the record date lead to significant, negative cumulative abnormal returns. In addition, some other significant information in terms of AR, AAR, CAR, CAAR and Precision Weighted CAAR are presented below:

\begin{tabular}{|c|c|c|c|c|c|}
\hline & $\mathrm{AR}$ & A A R & CAR $(-20,+20)$ & CAAR $(-20,+20)$ & $\begin{array}{l}\text { Precision } \\
\text { Weighted CAAR }\end{array}$ \\
\hline & $(\mathrm{T}$ test $)$ & (Pattel Z test) & ( $\mathrm{T}$ test $)$ & (Pattel Z test) & (Pattel Z test) \\
\hline $\begin{array}{c}2011 \\
(20 \text { companies })\end{array}$ & $\begin{array}{l}\text { Day }(-2) \text { and } \\
\text { Day }(-1) \text { are the } \\
\text { most significant } \\
\text { day (based on } \\
\text { t-statistic test). } \\
\text { Significant AR } \\
\text { registered for } 17 \% \\
\text { of the companies. }\end{array}$ & $\begin{array}{l}\text { Day }(-15) \text { to Day } \\
(-9), \text { Day }(-5) \text { to } \\
\text { Day }(+1) \text { and Day } \\
(+6) \text { to Day }(+8) \\
\text { are the most sig- } \\
\text { nificant from sta- } \\
\text { tistical point of } \\
\text { view (based on } \\
\text { Patell Z signifi- } \\
\text { cance test) }\end{array}$ & $\begin{array}{l}\text { Significant CAR } \\
\text { for: } 3 \text { of the } \\
\text { companies }\end{array}$ & $-6.98 \% *$ & $-4.33 \% *$ \\
\hline $\begin{array}{c}2012 \\
(26 \text { companies })\end{array}$ & $\begin{array}{l}\text { Day (-3), Day (- } \\
2 \text {, Day (-1) are } \\
\text { the most signifi- } \\
\text { cant days. Sig- } \\
\text { nificant AR regis- } \\
\text { tered for } 14 \% \text { of } \\
\text { the companies. }\end{array}$ & $\begin{array}{l}\text { Day }(-17) \text { to Day } \\
(+1), \text { Day }(6), \\
\text { Day (+11) and } \\
\text { Day }(+12) \text { are the } \\
\text { most significant } \\
\text { from statistical } \\
\text { point of view }\end{array}$ & $\begin{array}{l}\text { Significant CAR } \\
\text { for: } 4 \text { companies }\end{array}$ & $-1.5 \%$ & $-2.49 \%$ \\
\hline $\begin{array}{c}2013 \\
(25 \text { companies })\end{array}$ & $\begin{array}{l}\text { Day }(-2) \text {, Day (- } \\
\text { 1), Day (0) are } \\
\text { the most signifi- } \\
\text { cant. Significant } \\
\text { for } 16 \% \text { of the } \\
\text { companies. }\end{array}$ & $\begin{array}{l}\text { Day (-14) Day (- } \\
\text { 11) Day (-8) Day } \\
(-7) \text { Day }(-5) \text { Day } \\
(-2) \text { Day }(-1) \text { Day } \\
(0) \text { Day }(+1) \text { Day } \\
(+10) \text { day }(+13) \\
\text { are the most sig- } \\
\text { nificant from sta- } \\
\text { tistical point of } \\
\text { view }\end{array}$ & $\begin{array}{l}\text { Significant CAR } \\
\text { for: } 3 \text { companies }\end{array}$ & $9.11 \% *$ & $-2.16 \% *$ \\
\hline $\begin{array}{c}2014 \\
(24 \text { companies })\end{array}$ & $\begin{array}{l}\text { Day (-4), Day (- } \\
\text { 3) and Day }(-2) \\
\text { are the most sig- } \\
\text { nificant days. Sig- } \\
\text { nificant for } 16 \% \text { of } \\
\text { the companies. }\end{array}$ & $\begin{array}{l}\text { Day }(-18) \text { to } \\
\text { Day }(+3) \quad \text { and } \\
\text { Day(12) are the } \\
\text { most significant } \\
\text { from statistical } \\
\text { point of view }\end{array}$ & $\begin{array}{l}\text { Significant CAR } \\
\text { for: } 2 \text { companies }\end{array}$ & $2.59 \%$ & $-2.57 \%$ \\
\hline $\begin{array}{c}2015 \\
(33 \text { companies })\end{array}$ & $\begin{array}{l}\text { Day }(-1) \text {, Day }(0), \\
\text { Day }(+1) \text { are the } \\
\text { most significant } \\
\text { days. Significant } \\
\text { for } 14 \% \text { of the } \\
\text { companies. }\end{array}$ & $\begin{array}{l}\text { Day }(-1), \text { Day } \\
(+1) \text { are the most } \\
\text { significant from } \\
\text { statistical point } \\
\text { of view }\end{array}$ & $\begin{array}{l}\text { Significant CAR } \\
\text { for: } 5 \text { companies }\end{array}$ & $-1 \% *$ & $-4.3 \% *$ \\
\hline
\end{tabular}




\begin{tabular}{|c|c|c|c|c|c|}
\hline $\begin{array}{c}2016 \\
(33 \text { companies })\end{array}$ & $\begin{array}{l}\text { Day }(+1), \text { Day } \\
(+2), \text { Day }(+5) \\
\text { Day }(+7) \text { are the } \\
\text { most significant } \\
\text { days. Significant } \\
\text { for } 10 \% \text { of the } \\
\text { companies. }\end{array}$ & $\begin{array}{l}\text { Day }(-1), \text { Day }(0), \\
\text { Day }(+1), \text { Day } \\
(+2), \text { Day }(+4), \\
\text { Day }(+6) \text { are the } \\
\text { most significant } \\
\text { from statistical } \\
\text { point of view }\end{array}$ & $\begin{array}{l}\text { Significant CAR } \\
\text { for: } 5 \text { companies }\end{array}$ & $-2.52 \% *$ & $-3.37 \% *$ \\
\hline
\end{tabular}

As in the case of the ex-dividend date, the Precision Weighted CAARs for the holding period of 41 days around the event are negative and statistically significant, varying from $-4.33 \%$ to $-2.16 \%$.

Based on non-parametric tests (results presented in Annex 2), the existence of abnormal returns around the record date in significant. The rejection rate of null hypothesis (which says that CAAR is 0 ) is between $67 \%$ to $100 \%$.

The results reject the null hypothesis for all considered events, contradicting the market efficiency hypothesis in the case of Romania. Therefore, investors can profit from these occasions and obtain significant abnormal returns.

When looking at the dividend announcement event, we observe significant abnormal returns registered after the declaration day. We cannot find any evidence on information leakage. Results indicate that information was not available prior to the declaration date, as significant price reactions can be seen on day 0 (the announcement date). Moreover, taking into consideration that stock prices are partly driven by market expectations and forecasts, if the dividend amount to be paid is aligned with expectations, prices will not move. On the other hand, if dividend changes convey unexpected information, market sentiment about the company would shift depending on how this action would be perceived by analysts as a good or bad move. This would dictate in some manner the stock price evolution for the following moments/days. Capital markets react favorably to dividend increases, perceived as "good news" and adversely to dividend cuts, portrayed as "bad news". However, the intensity of the reaction is far greater in the case of dividend reductions, investors seeing them as a negative signal of future earnings' deterioration (Lease et al., 2000). Furthermore, due to the fact that some dividend announcement dates may come along with other preliminary last year's earnings announcements (according to Romanian Law, companies have to disclose their yearly financial situation with the Ministry of Finance until the end of May) or other press releases, the stock price may decrease to adjust for more than the lost dividend. Some other market forces that may affect the stock prices have to be considered as well when explaining the magnitude of the drop, which is not the same as the dividend amount. Also, as volatility persists several days after the announcement, we can assume that investors are trading based on dividend signal, therefore supporting the dividend signaling theory. Results are in line with Lonie et al. (1996), Adelegan (2003), Gurgul et al. (2003), McClusky et al. (2006) and Dasilas and Leventis (2011).

As opposed to the declaration date, when most of the volatility happens after the event day, the ex-dividend and record date show a different market behavior, prices recording a higher volatility before day 0. Furthermore, analyzing stocks' price behavior, findings support Kalay's (1982) short term trading hypothesis. When looking at the ex-dividend date, a great part of the abnormal returns are positive before the event date and negative after, proving the existence of dividend capture traders, who buy the stocks before the ex-dividend date and sell them shortly afterwards. It is important to emphasize here, that when the company states its dividend policy for the current year, it also settles the ex-dividend date. As soon as the market opens on the exdividend date, market would adjust the company's price with the dividend amount. However, if an investor buys the stock even with a day prior to the ex-dividend date, he can afterwards sell the stock whenever he wants, even if it is on the ex-dividend date or after and he would still 
receive the dividend. The investors do not have to hold the stock until the payment date. This is how they can time the market and profit on the short term by earning the stock's dividend without maintaining this share in their portfolio for a long period. Moreover, if a trader is not interested in a stock's dividend that may come along with a share price depreciation but it is only attracted by short term gains from market movement, he can still benefit from this strategy. The positive abnormal returns start from several days before the ex-dividend date. A trader may want to benefit from those rising returns and sell the stock at its peak, right before the closing day prior to the ex-dividend date.

In comparison to the ex-dividend date, while we acknowledge the importance of the record date of dividends, this seems to be administrative. It determines the eligible shareholders that owned the stock prior to the ex-dividend date. Therefore, the abnormal returns registered in the proximity of this date are significantly lower than the ones registered close to the ex-dividend date. This is because the record date is settled one to four days following the ex-dividend date. For the companies in our data set, the record date comes 2 days after the ex-dividend date. Nevertheless, timing trading strategies may be a possibility in this case as well. We observe that these significant abnormal returns are driven by the demand of stocks with higher dividend yields. Same results were obtained by Lakonishok and Vermaelen (1986), Naranjo et al. (2000) and Dutta et al. (2004).

\section{Conclusions, Limitations And neXt Steps}

We analyzed the extent to which market share prices are driven by dividend announcements and the possibility of attaining abnormal returns if trading based on these events. We provide evidence that significant positive/negative abnormal returns could be registered around the Dividend Announcement date, Ex-Dividend Date and Record Date. The most significant Days when the shareholders could gain from abnormal return, in an event window of $(-20,+20)$ around the dividend announcement date are: Day $(0)$, Day $(+1)$, Day $(+2)$, Day $(+4)$, Day $(+5)$, Day $(+7)$.

In the same time, Ex-Dividend and Record Dates seem to generate statistically significant abnormal returns through CAAR, AR, AAR. CAAR revealing that these two dividend events could lead to negative market reactions when looking at companies listed on the Bucharest Stock Exchange. Therefore, we can sustain that investors could benefit from lower stock prices after these dates, and they can buy Romanian stock in this specific days. On the other hand, if we compare the three dividend dates, we can see that the dividend declaration date provides information that is incorporated in the price in a longer period (more days with significant abnormal returns after the declaration date). For ex-dividend date and record date, there is only one immediate effect. This finding is in line with Charest's (1978) and Eades's et al. (1985) findings.

The findings on Romanian capital market reaction to dividend dates can be replicated to other emerging markets.

Hence, we add to the existing literature a better understanding of the Romanian market response to dividend events and provide insights on the speed of information's integration within stock prices. Also, the results of the study strongly support the information role of dividends.

In the same time, taking into consideration that dividend events influence significantly the existence of abnormal returns, it means that the shareholders care about dividends in Romania, and they analyze the level of dividends when deciding to invest in one company or another. Therefore, from regulatory perspective, the dividend distribution should be encouraged, but only after investing in profitable projects that could lead to higher dividends in the future.

In a future study, it will be interesting to split the database between different dividend changes categories: i) increase dividends, ii) decrease dividends, iii) keep the same dividends as in the year before. For example, we proved that the CAAR and AAR are significant in most of the years, but in some years the CAAR is positive and in some years it is negative. 
Therefore, as we expected, the market reactions are different from one year to another based on the different types of change in the dividend policy.

There could be also econometric limitations when using event studies. The problems can be divided in two main categories:

(i) Misspecifications of expected returns (misleading inference due to bias in the estimates of abnormal returns).

(ii) Non-random sample, leading to non-normal distributions

However, this methodology is usually used in the event studies in the past literature. Also, to mitigate potential econometric limitations we performed also the non-parametric tests. These support the assumption of the existence of abnormal returns around the dividend dates.

In a further research study, we would like to implement also regression analysis to provide a better view on the impact of dividend events on the CAAR and on AR. There might be the situation that these abnormal returns are not registered because of the announcement of dividends, but because of other circumstances. Therefore, the regression analysis could help us to see the determination ratio between the abnormal returns and the level of dividend per share.

\section{REFERENCES}

[1] Adelegan, O. J. (2003). Capital market efficiency and the effects of dividend announcements on share prices in Nigeria. African Development Review, 15(2-3), 218-236.

[2] Aharony, J. and Swary, I. (1980). Quarterly Dividend and Earnings Announcements and Stockholders' Returns: An Empirical Analysis.

[3] Asquith, P. and Mullins, D.,W. (1983). The Impact of Initiating Dividend Payments on Shareholders' Wealth. The Journal of Business. Vol. 56, No. 1 (Jan., 1983), pp. 77-96.

[4] Battacharya S. (1979). Imperfect information \& dividend policy and the 'bird in hand' fallacy. The Bell Journal of Economics, Vol. 10, pp. 259-270.

[5] Benesh, G.A. and Keown, A. J. (1984). An Examination Of Market Reaction To Substantial Shifts In Dividend Policy. The Financial Review, Vol. 17, Issue 2.

[6] Boehmer, E., Musumeci, J. and Poulsen, A. (1991). Event study methodology under conditions of eventinduced variance. Journal of Financial Economics, 30(2), 253-272.

[7] Brickley, J. (1983). Shareholder wealth, information signaling and the specially designated dividend: An empirical study. Journal of Financial Economics, Vol.12, Issue 2, 187-209.

[8] Brown, S. J. and Warner, J. B. (1985). Using daily stock returns: The case of event studies. Journal of financial economics, 14(1), 3-31.

[9] Campbell, J., Lo, A., Mackinley, A. (1997). The Econometrics of Financial Market. Macroeconomic Dynamics 2(04), 559-562.

[10] Charest,G. (1978). Dividend information, stock returns and market efficiency-II. Journal of Financial Economics. Vol. 6, Issue 2-3, 297-330.

[11] Chordia, T., Subrahmanyam, A. and Tong, Q. (2014). Have capital market anomalies attenuated in the recent era of high liquidity and trading activity?. Journal of Accounting and Economics 58 (1):41-58.

[12] Corrado, C. J., \& Zivney, T. L. (1992). The specification and power of the sign test in event study hypothesis tests using daily stock returns. Journal of Financial and Quantitative analysis, 27(3), 465-478.

[13] Cowan, A. R., \& Sergeant, A. M. (1996). Trading frequency and event study test specification. Journal of Banking \& Finance, 20(10), 1731-1757.

[14] Dasilas, A. and Leventis, S. (2011). Stock market reaction to dividend announcements: Evidence from the Greek stock market. International Review of Economics \& Finance, 20(2), 302-311.

[15] De Cesari, A., Huang-Meier, W. (2015). Dividend changes and stock price informativeness. Journal of Corporate Finance, Elsevier, vol. 35(C), pages 1-17.

[16] Dragotă, V. (2003). Politica de dividend: o abordare în contextul mediului economic din România. Ed. All Beck.

[17] Dragotă, V., Dragotă, M., Stoian, A. (2004). Some Considerations about Stock Prices and Fair Market Value on Romanian Capital Market. In D. Popescu (Ed.), România - exigenţe în procesul dezvoltării, în perspectiva integrării în anul 2007 (pp. 224-231). Sibiu: Editura Universitatii „Lucian Blaga” din Sibiu.

[18] Dragotă, I. M., Dragotă, V., Tâţu, L. and Tâţu, D. (2009). Income Taxation Regulation And Companies' Behaviour: Is The Romanian Companies' Dividend Policy Influenced By The Changes In Income Taxation?. Romanian Journal of Economic Forecasting, 10(1), 76-93.

[19] Dutta, S., Jog, V. M., Saadi, S. (2004). Re-examination of the ex-dividend day behaviour of Canadian stock prices. Working Papers Series, University of Ottawa, Canada. 
[20] Eades, K.M., Hess, P.J., Kim, H. E. (1985). Market Rationality and Dividend Announcements. Journal of Financial Economics 14, 581-604.

[21] Easterbrook, F. (1984). Two agency-cost explanations of dividends. American Economic Revies. 74, 650659.

[22] Esqueda, A.O. (2016). Signaling, corporate governance, and the equilibrium dividend policy. The Quaterly Review of Economics and Finance, Vol. 59, 186-199.

[23] Frankfurter, G. M. and Lane, W. R. (1992). The rationality of dividends. International Review of Financial Analysis, 1(2), 115-129.

[24] Gurgul, H., Mestel, R. and Schleicher, C. (2003). Stock market reactions to dividend announcements: Empirical evidence from the Austrian stock market. Financial Markets and Portfolio Management, 17(3), 332-350.

[25] Healy, P. and Palepu, K. (1988). Earnings information conveyed by dividend initiations and omissions. Journal of Financial Economics. Vol. 21, Issue 2, 149-175.

[26] Howatt, B., Zuber, R., Gandar, J. and Lamb, R. (2009). Dividends, earnings volatility and information. Applied Financial Economics, 19, 551-562.

[27] Ivănescu, D. and Ivănescu, I. (2009). Aspects Of Dividend Policy In Romania. Finance and economic stability in the context of financial crisis, 517-522.

[28] Jensen, G.R. and Johnson, R.R. (1995). Discount rate changes and security returns in the U.S., 1962-1991. Journal of Baking and Finance, Vol. 19, Issue 1, 79-95.

[29] John, K. and Lang, L.H.P. (1991). Insider trading around dividend announcements: Theory and evidence. The Journal of Finance, Vol. 46, Issue 4, 1361-1389.

[30] John, K. and Williams, J. (1985). Dividends, dilution, and taxes: A signalling equilibrium. The Journal of Finance, 40(4), 1053-1070.

[31] Kalay, A. (1982). The ex-dividend day behavior of stock prices: a re-examination of the clientele effect. The Journal of Finance, 37(4), 1059-1070.

[32] Kolari, J. W., \& Pynnönen, S. (2010). Event study testing with cross-sectional correlation of abnormal returns. The Review of financial studies, 23(11), 3996-4025.

[33] Kolari, J. W., \& Pynnonen, S. (2011). Nonparametric rank tests for event studies. Journal of Empirical Finance, 18(5), 953-971.

[34] Lakonishok, J. and Vermaelen, T. (1986). Tax-induced trading around ex-dividend days. Journal of Financial Economics, 16(3), 287-319.

[35] Lang, H. and Litzenberger, R. (1989). Dividend announcements: Cashflow signaling vs free cashflow hypothesis. Journal of Financial Economics,24, 181-191.

[36] Lease, R. C., John, K., Kalay, A., and Loewenstein, U. (2000). Dividend Policy: It's Impact on Firm Value, Harvard Business School.

[37] Lin, T.J., Chen.Y.P., Tsai, H.F. (2017). The relationship among information asymmetry, dividend policy and ownership structure. Finance Research Letters, Vol. 20, 1-12.

[38] Lonie, A. A., Abeyratna, G., Power, D. M. and Sinclair, C. D. (1996). The stock market reaction to dividend announcements. Journal of Economic Studies, 23(1), 32-52.

[39] MacKinlay, A. C. (1997). Event studies in economics and finance. Journal of economic literature, 35(1), $13-39$.

[40] McClusky, T., Burton, B. M., Power, D. M. and Sinclair, C. D. (2006). Evidence on the Irish stock market's reaction to dividend announcements. Applied Financial Economics, 16(8), 617-628.

[41] Miller M. H. and Modigliani, F. (1961). Dividend policy, growth and the valuation of shares. The Journal of Business, Vol. 34, pp. 411-433.

[42] Miller, M. H. and Rock, K. (1985). Dividend Policy under Asymmetric Information. The Journal of Finance, 40(4), 1031-1051.

[43] Naranjo, A., Nimalendran, M. and Ryngaert, M. (2000). Time variation of ex-dividend day stock returns and corporate dividend capture: A reexamination. The Journal of Finance, 55(5), 2357-2372.

[44] Nissim, D. and Ziv, A. (2001). Dividend changes and future profitability. The Journal of Finance, 56(6), 2111-2133.

[45] Ofer, A. and Seigel, D. (1987). Corporate Financial Policy, Information, and Market Expectations: An Empirical Investigation of Dividends. The Journal of Finance, Col. 41, Issue 4, 889-911.

[46] Ofer, A. R. and Thakor, A. V. (1987). A theory of stock price responses to alternative corporate cash disbursement methods: Stock repurchases and dividends. The Journal of Finance, 42(2), 365-394.

[47] Patell, J. M. (1976). Corporate forecasts of earnings per share and stock price behavior: Empirical test. Journal of accounting research, 14(2), 246-276.

[48] Patell, J.M. and Wolfson, M.A. (1984). The Intraday Speed of Adjustment of Stock Prices to Earnings and Dividend Announcements. Journal of Financial Economics, 13, 223-252.

[49] Petit R. R. (1972). Dividend announcements, security performance, and capital market efficiency. Journal of Finance, Vol. 27, pp. 993-1007. 
[50] Rani, N. (2016). Mergers and Acquisitions. India Studies in Business and Economics. DOI 10.1007/978981-10-2203-6_2.

[51] Schwert, G. W. (2003). Anomalies and market efficiency. Handbook of the Economics of Finance 1:939-974.

[52] Todea, A., Metes, C.A. (2005). Impactul anuntului majorarii de capital asupra cursului bursier: cazul Bursei de Valori Bucuresti. In: Finantele si Integrarea în Uniunea Europeana Bucuresti: Editura ASE.

[53] Veronesi, P. (1999). Stock market overreactions to bad news in good times: a rational expectations equilibrium model. The Review of Financial Studies 12 (5), 975-1007.

[54] Woolridge, J. R. and Ghosh, C. (1985). Dividend cuts: Do they always signal bad news. Midland Corporate Finance Journal, 3(2), 20-32.

[55] Yılmaz, M. K. and Gunay, G. (2006). Dividend Policies and Price-Volume Reactions to Cash Dividends on the Stock Market. Emerging Markets Finance \& Trade, 42 (4), 19-49. 


\begin{tabular}{|c|c|c|c|c|c|c|}
\hline & $\begin{array}{l}\text { Pescriptive } \\
11-2016\end{array}$ & tistics of & stock ret & is per co & ny for the & \\
\hline & & Entire pe & & & & \\
\hline & & No. obs. & Average & Max & Min & Std. dev. \\
\hline 1 & ALR & 1408 & $0.0 \%$ & $31.4 \%$ & $-16.1 \%$ & $2.7 \%$ \\
\hline 2 & $\mathrm{ALU}$ & 1358 & $0.0 \%$ & $39.6 \%$ & $-16.3 \%$ & $2.9 \%$ \\
\hline 3 & ALS & 1376 & $0.1 \%$ & $14.0 \%$ & $-38.9 \%$ & $2.7 \%$ \\
\hline 4 & ARTE & 1033 & $0.1 \%$ & $14.6 \%$ & $-15.8 \%$ & $4.0 \%$ \\
\hline 5 & ATB & 1665 & $0.0 \%$ & $6.9 \%$ & $-17.6 \%$ & $1.5 \%$ \\
\hline 6 & $\mathrm{BCM}$ & 971 & $0.0 \%$ & $11.9 \%$ & $-16.1 \%$ & $2.9 \%$ \\
\hline 7 & $\mathrm{BIO}$ & 1663 & $0.0 \%$ & $11.0 \%$ & $-9.0 \%$ & $1.5 \%$ \\
\hline 8 & BRD & 1680 & $0.0 \%$ & $5.3 \%$ & $-7.6 \%$ & $1.4 \%$ \\
\hline 9 & BRM & 730 & $0.0 \%$ & $14.0 \%$ & $-16.3 \%$ & $4.2 \%$ \\
\hline 10 & BVB & 1665 & $0.0 \%$ & $9.1 \%$ & $-16.2 \%$ & $1.6 \%$ \\
\hline 11 & $\mathrm{CBC}$ & 473 & $0.2 \%$ & $14.0 \%$ & $-23.9 \%$ & $7.6 \%$ \\
\hline 12 & CMCM & 285 & $-0.3 \%$ & $14.0 \%$ & $-16.3 \%$ & $6.7 \%$ \\
\hline 13 & CMF & 491 & $0.0 \%$ & $14.0 \%$ & $-16.2 \%$ & $4.8 \%$ \\
\hline 14 & CNTE & 791 & $-0.1 \%$ & $14.0 \%$ & $-16.2 \%$ & $2.7 \%$ \\
\hline 15 & COTE & 929 & $0.0 \%$ & $13.8 \%$ & $-28.7 \%$ & $2.1 \%$ \\
\hline 16 & COTR & 513 & $0.0 \%$ & $14.0 \%$ & $-16.3 \%$ & $5.5 \%$ \\
\hline 17 & EFO & 1356 & $0.0 \%$ & $13.9 \%$ & $-15.1 \%$ & $2.7 \%$ \\
\hline 18 & EL & 799 & $0.0 \%$ & $5.2 \%$ & $-7.7 \%$ & $1.2 \%$ \\
\hline 19 & ELGS & 1466 & $0.0 \%$ & $29.8 \%$ & $-61.7 \%$ & $4.3 \%$ \\
\hline 20 & ELMA & 1366 & $0.0 \%$ & $13.6 \%$ & $-14.2 \%$ & $2.1 \%$ \\
\hline 21 & FP & 1659 & $0.0 \%$ & $5.6 \%$ & $-7.3 \%$ & $1.2 \%$ \\
\hline 22 & IARV & 939 & $0.2 \%$ & $22.3 \%$ & $-14.3 \%$ & $3.2 \%$ \\
\hline 23 & MECF & 752 & $0.1 \%$ & $14.0 \%$ & $-16.3 \%$ & $4.4 \%$ \\
\hline 24 & OIL & 1559 & $0.0 \%$ & $14.0 \%$ & $-16.3 \%$ & $2.5 \%$ \\
\hline 25 & PREH & 619 & $-0.1 \%$ & $14.0 \%$ & $-30.6 \%$ & $5.6 \%$ \\
\hline 26 & PTR & 1367 & $0.0 \%$ & $14.0 \%$ & $-13.4 \%$ & $2.6 \%$ \\
\hline 27 & RMAH & 807 & $0.1 \%$ & $14.0 \%$ & $-14.2 \%$ & $3.4 \%$ \\
\hline 28 & $\mathrm{ROCE}$ & 1278 & $-0.1 \%$ & $13.9 \%$ & $-16.2 \%$ & $3.1 \%$ \\
\hline 29 & SCD & 1507 & $0.1 \%$ & $14.0 \%$ & $-16.2 \%$ & $2.2 \%$ \\
\hline 30 & SFG & 232 & $0.7 \%$ & $6.1 \%$ & $-4.9 \%$ & $2.1 \%$ \\
\hline 31 & SIF1 & 1671 & $0.1 \%$ & $13.3 \%$ & $-11.9 \%$ & $1.7 \%$ \\
\hline 32 & SIF2 & 1672 & $0.0 \%$ & $11.3 \%$ & $-71.5 \%$ & $2.4 \%$ \\
\hline 33 & SIF3 & 1680 & $0.0 \%$ & $13.7 \%$ & $-66.2 \%$ & $2.5 \%$ \\
\hline 34 & SIF4 & 1669 & $0.0 \%$ & $649.8 \%$ & $-648.4 \%$ & $22.5 \%$ \\
\hline 35 & SIF5 & 1681 & $0.0 \%$ & $598.7 \%$ & $-599.5 \%$ & $45.4 \%$ \\
\hline 36 & SNG & 958 & $0.0 \%$ & $282.1 \%$ & $-281.9 \%$ & $13.0 \%$ \\
\hline 37 & SNN & 960 & $0.0 \%$ & $410.2 \%$ & $-409.1 \%$ & $18.8 \%$ \\
\hline 38 & SNP & 1682 & $0.0 \%$ & $743.3 \%$ & $-746.5 \%$ & $55.4 \%$ \\
\hline 39 & SOCP & 1234 & $0.0 \%$ & $793.9 \%$ & $-794.0 \%$ & $84.3 \%$ \\
\hline 40 & SPCU & 1045 & $0.0 \%$ & $872.4 \%$ & $-866.5 \%$ & $53.8 \%$ \\
\hline 41 & TEL & 1661 & $0.0 \%$ & $364.0 \%$ & $-366.7 \%$ & $24.1 \%$ \\
\hline 42 & TGN & 1667 & $0.0 \%$ & $77.0 \%$ & $-77.7 \%$ & $4.5 \%$ \\
\hline 43 & TLV & 1668 & $0.0 \%$ & $9.4 \%$ & $-30.1 \%$ & $1.9 \%$ \\
\hline 44 & TRP & 1283 & $0.0 \%$ & $14.0 \%$ & $-44.0 \%$ & $4.1 \%$ \\
\hline 45 & TUFE & 1003 & $0.0 \%$ & $14.0 \%$ & $-822.5 \%$ & $102.7 \%$ \\
\hline
\end{tabular}


Annex 2 - Results of Non-Parametric Tests

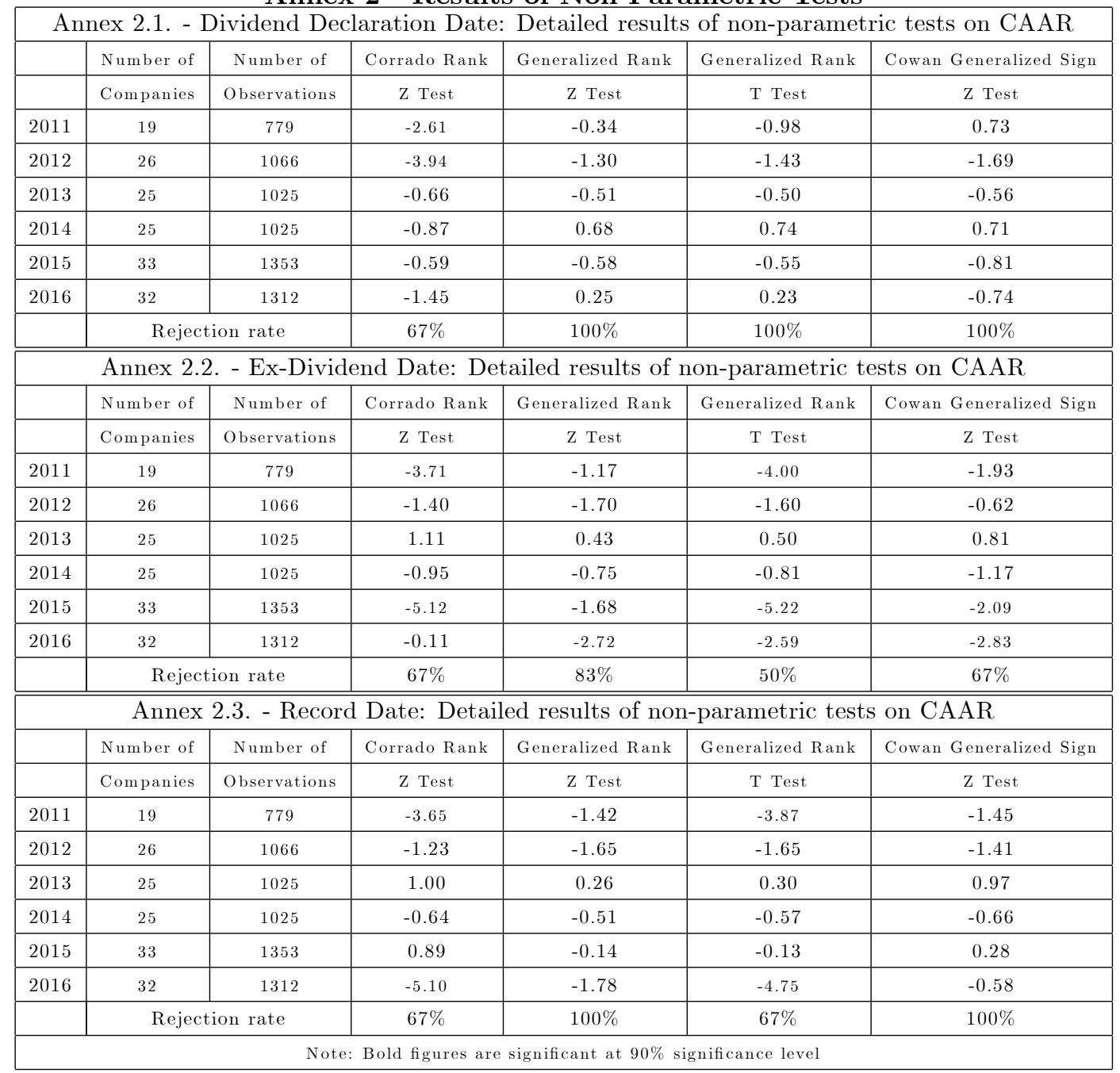

